Jurnal Kesmas Asclepius

Volume 1, Nomor 2, Desember 2019

e-ISSN: 2684-8287

p-ISSN: 2656-8926

DOI: https://doi.org/10.31539/jka.v1i2.818

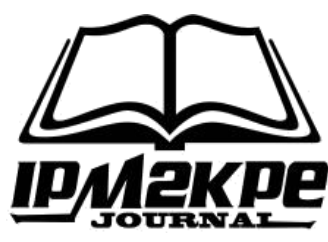

\title{
DAMPAK PROGRAM PENGEMBANGAN PELATIHAN TERHADAP KINERJA PERAWAT RSIJ CEMPAKA PUTIH DENGAN MODEL PENDEKATAN SYSTEM DYNAMICS
}

\author{
Budi Hartono ${ }^{1}$, Nisa Afriza ${ }^{2}$ \\ Universitas Muhammadiyah Jakarta ${ }^{1}$ \\ Universitas Terbuka Jakarta ${ }^{2}$ \\ coachbudihartono@gmail.com ${ }^{1}$
}

\begin{abstract}
ABSTRAK
Penelitian ini bertujuan untuk melihat berapa besarnya program pengembangan perawat Rumah Sakit Islam Jakarta Cempaka Putih berpotensi memberikan pengaruh terhadap kinerja perawat Rumah Sakit Islam Jakarta Cempaka Putih. Metode penelitian yang dilakukan dalam penelitian ini adalah dengan menggunakan Pendekatan System Dynamic (Dinamika Sistem). Hasil pemodelan menggunakan data historis menunjukkan bahwa progam pengembangan pelatihan dalam jangka panjang memperlihatkan penurunan sehingga berdampak pada kinerja perawat yang juga menujukkan perilaku menurun sedangkan hasil pemodelan berdasarkan simulasi menunjukkan peningkatan yang signifikan terhadap kinerja perawat jika dilakukan peningkatan kebijakan target jam program pengembangan pelatihan perawat berdasarkan target jam dari HPMI. Simpulan, kinerja perawat RSIJ Cempaka Putih sebenarnya menunjukan perilaku yang menurun, berbeda dengan kinerja yang dilaporkan berdasarkan Key Performnce Indicator (KPI) dan Performance Appraisal bahwa kinerja perawat dominan sesuai standar sampai istimewa.
\end{abstract}

Kata Kunci: Kinerja, Kompetensi, Motivasi Pelatihan, System Dynamics

\begin{abstract}
This study aims to see how much the nurse development program of the Jakarta Cempaka Putih Islamic Hospital has the potential to influence the performance of nurses at the Cempaka Putih Islamic Hospital. The research method used in this research is to use the Dynamic System Approach (System Dynamics). The results of modeling using historical data show that the training development program in the long term shows a decrease so that it has an impact on the performance of nurses which also shows decreased behavior while the results of modeling based on simulations show a significant increase in nurse performance if an increase in the policy target hours of the nurse training development program is based on target hours from HPMI. In conclusion, the performance of nurses at RSIJ Cempaka Putih actually shows decreased behavior, which is different from the performance reported based on the Key Performance Indicator (KPI) and Performance Appraisal that the dominant nurse's performance is up to standard.
\end{abstract}

Keywords: Performance, Competence, Training Motivation, System Dynamics 


\section{PENDAHULUAN}

Rumah sakit yang merupakan salah satu dari sarana kesehatan, merupakan rujukan pelayanan kesehatan dengan fungsi utama menyelenggarakan upaya kesehatan yang bersifat penyembuhan dan pemulihan bagi pasien (Depkes, 2004). Rumah Sakit Islam Jakarta Cempaka Putih didirikan tanggal 18 April 1967 sudah terakreditasi paripurna KARS versi 2012 pada tanggal 5 Agustus 2016. Hal tersebut terwujud karena peran serta dan dukungan dari seluruh elemen sumber daya dan sumber daya manusia yang dimiliki, salah satunya peran perawat sebagai salah satu tenaga SDM terbesar di rumah sakit.

Perawat sebagai salah satu tenaga professional yang mempunyai peran dan posisi strategis dalam pelayanan kesehatan, yang 24 jam kontak langsung dengan pasien perlu memperbaiki performance sehari-hari, dengan merubah kebiasan yang tadinya lebih bersifat vokasional menjadi keperawatan profesional, mandiri, dan terintegrasi yang tinggi dengan tenaga medis lainnya di rumah sakit. Berdasarkan UU RI nomor 44 tahun 2009 pendidikan dan pelatihan sumber daya manusia dalam rangka peningkatan kemampuan dalam pemberian pelayanan kesehatan merupakan salah satu fungsi rumah sakit. Hal ini juga sesuai dengan firman-Nya ; "Serulah (manusia) kepada jalan Tuhanmu dengan hikmah dan pelajaran yang baik dan bantahlah mereka dengan cara yang baik". (Al-Qur'an, 16:125). Allah menjelaskan bahwa dalam melakukan pembinaan dan pengembangan terhadap pegawai atau SDM, hendaknya melalui hikmah. Salah satu cara, yaitu melalui pemberian pelatihan (training) untuk meningkatkan kompetensi perawat. Hal ini dikarenakan dengan diadakannya pelatihan, maka organisasi melakukan investasi jangka panjang terhadap pengembangan nilai yang dimiliki organisasi, sedangkan pengembangan perawat adalah komponen kunci dalam strategi mempertahankan perawat dan menyiapkan mereka untuk mengembangkan karir dalam organisasi tersebut (Rohmatullah, 2017).

Himpunan Perawat Manajer Indonesia (HPMI) dalam Modul pelatihan Komite Keperawatan menyatakan bahwa program peningkatan mutu profesi perawat salah satu indikator mutunya adalah jam pengembangan praktik profesi per individu perawat melalui pelatihan/seminar yaitu minimal $38 \mathrm{jam} / \mathrm{minggu} \times 12 \mathrm{minggu}=456 \mathrm{jam} / \mathrm{tah} u n$ (HPMI, 2017). Sedangkan kebijakan yang ditetapkan oleh manajemen RSIJ Cempaka putih yang tertuang dalam salah satu instrumen evaluasi Key Performance Indikator (KPI) yaitu pelatihan yang harus diikuti adalah 20jam/tahun. Hal ini menunjukkan bahwahanya 4\%jumlah jam pelatihan perawat yang dijadikan capaian dalam indikator penilaian kinerja perawat (KPI) dari 456 jam yang seharusnya diperoleh atau dicapai oleh setiap perawat.

Hal tersebut dapat diartikan bahwa kinerja merupakan perwujudan perilaku kerja seorang perawat yang ditampilkan sebagai prestasi kerja sesuai dengan peranannya dalam sebuah rumah sakit dalam jangka waktu tertentu. Islam menjadikan kerja sebagai sumber nilai insane dan ukuran yang tanggungjawabnya berbeda. Kerja juga merupakan sumber yang objektif bagi penilai prestasi manusia berdasarkan segi kelayakan. Artinya kinerja perawat yang berkualitas dan professional merupakan kebutuhan mutlak bagi rumah sakit terutama untuk dapat mempertahankan pengakuan akreditasi Paripurna tersebut, maka RSIJ Cempaka Putih terus menerus melakukan upaya perbaikan kinerja sebagai langkah awal dari proses continuous quality improvement dalam pelayanan kesehatan (SDM RSIJ, 2015). 
Berdasarkan survei pendahuluan yang peneliti lakukan terhadap data kepegawaian RSIJ Cempaka Putih, diperoleh data yaitu jumlah tenaga keperawatan di RSIJ adalah sebanyak 435 orang perawat dan bidan, dimana jumlah terbanyak adalah perawat dengan pendidikan Diploma ke atas. Berdasarkan informasi yang diperoleh dari bagian HRD dan Komite Keperawatan diketahui bahwa dari 435 orang perawat dan bidan tersebut yang memiliki masa kerja $\geq 5$ tahun yaitu sebanyak 54 orang.

Berdasarkan fenomena di atas peneliti berpendapat bahwa adanya kualitas kinerja perawat yang meningkat dapat memberikan dampak positif bagi masyarakat sebagai penerima pelayanan kesehatan begitu pula sebaliknya jika kinerja perawat terjadi penurunan maka dapat berdampak negatif terhadap pelayanan yang akan diterima oleh masyarakat. Kinerja perawat sendiri dapat ditingkatkan melalui peningkatan kompetensi perawat yang didapat melalui pengembangan pelatihan perawat.

\section{METODE PENELITIAN}

Metode penelitian yang dilakukan dalam penelitian ini adalah dengan menggunakan pendekatan system dynamic (dinamika sistem). Dimana proses penggunaan metoda ini didasari pertimbangan bahwa metoda ini mampu merepresentasikan keterkaitan antar variabel-variabel yang dikaji dan mampu menggambarkan interaksi dari masing-masing sistem serta mensimulasikan perilaku sistem apabila dilakukan intervensi terhadap sistem tersebut. Penggunaan system dynamic lebih menekankan pada tujuan peningkatan pemahaman tentang bagaimana perilaku dimunculkan oleh struktur eksisting, pemahaman ini sangat penting dalam perancangan kebijakan yang efektif atau melihat arah kebijakan yang lebih baik untuk memunculkan perilaku sistem yang diharapkan. Stakeholder dalam penelitian adalah perawat dengan masa kerja $\geq 5$ tahun yang bekerja di RSIJ Cempaka Putih sebanyak 54 orang, manajer SDI dan ketua komite keperawatan.

Dalam penelitian ini teknik analisis yang digunakan adalah aplikasi perangkat lunak Vensim PLE 7.2.

HASIL PENELITIAN

Simulasi Model System Dynamics Causal Loop Diagram(CLD)

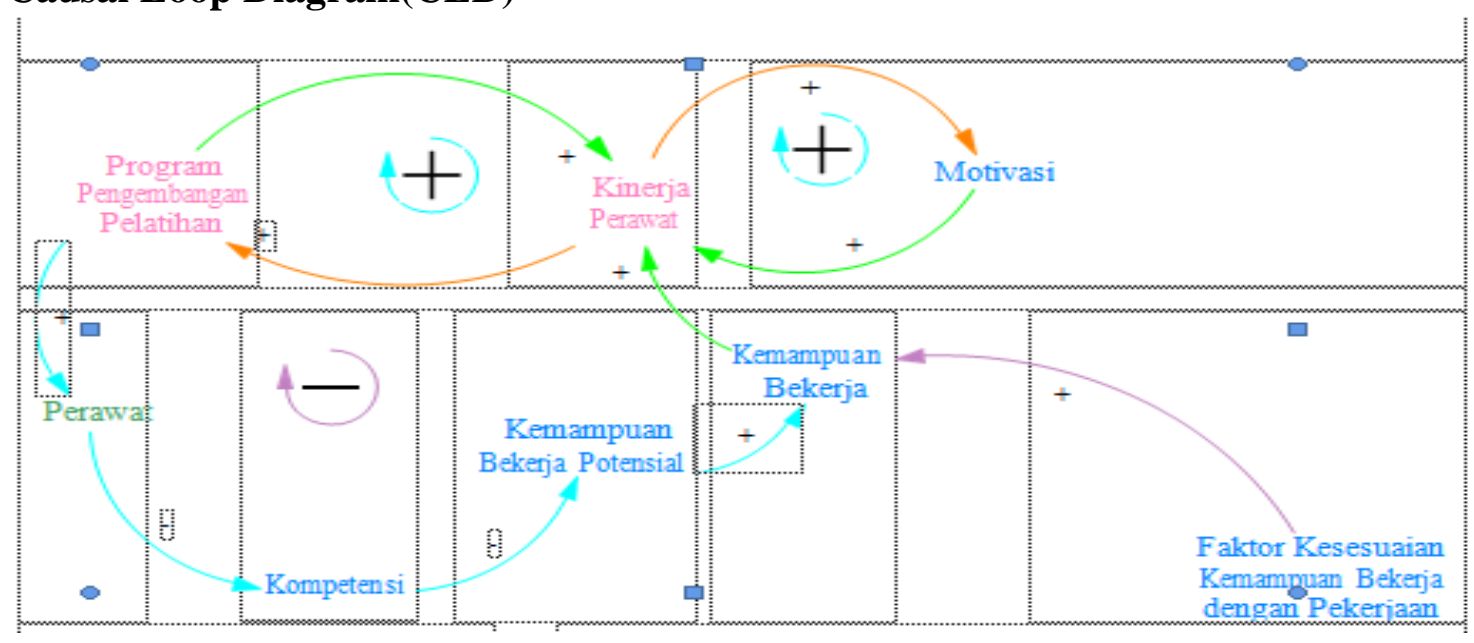

Gambar. 1

Causal Loop Diagram Dampak Program Pengembangan Pelatihan terhadap Kinerja Perawat 
Berdasarkan gambar di atas bahwa kinerja perawat dipengaruhi oleh program pengembangan pelatihan perawat dan motivasi, ada 2 loop positif dan 1 loop negatif.

\section{Stock Flow Diagram}

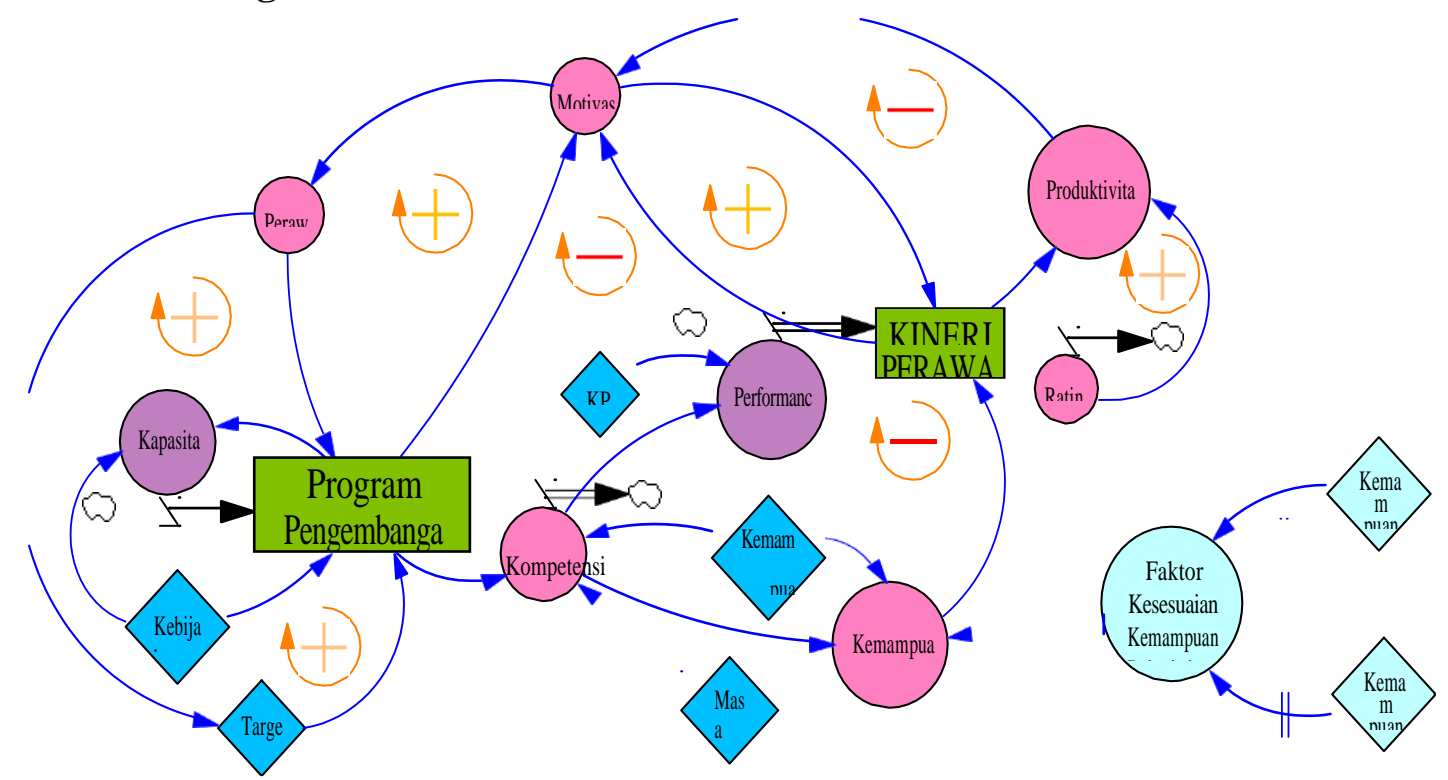

Gambar. 2

Stock Flow Diagram

Berdasarkan gambar diatas digambarkan program pengembangan pelatihan dalam upaya meningkatkan kinerja perawat

\section{Analisis Kebijakan Peningkatan Kinerja Perawat RSIJ Cempaka Putih Perilaku Model Kinerja Perawat}

KINERJA PERAWAT

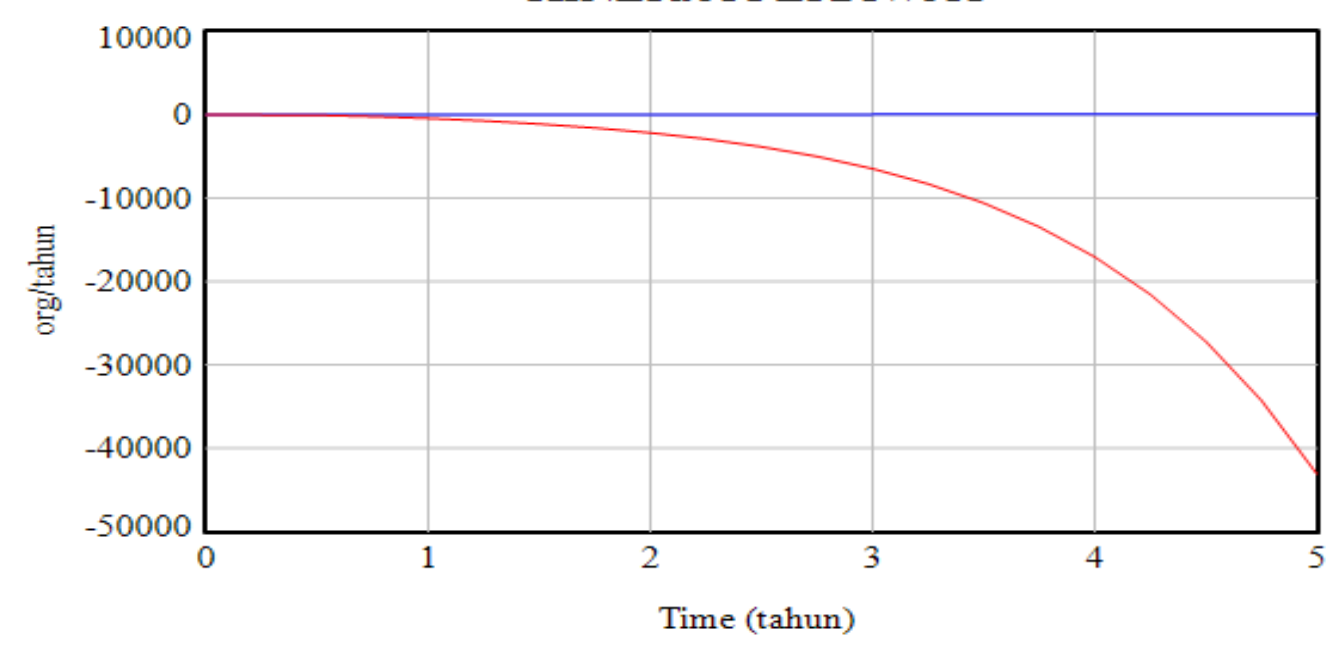

Gambar. 3

Grafik Perilaku Model Kinerja Perawat 
Berdasarkan gambar di atas dapat diartikan bahwa kinerja perawat berdasarkan pola data riil dengan asumsi rating nilai kinerja 85 (sesuai standar) cenderung mengalami penurunan yang signifikan sampai 5 tahun (tahun 2023), dibandingkan dengan perilaku kinerja perawat setelah disimulasikan dengan asumsi rating nilai kinerja ditingkatkan menjadi 105 (istimewa), kinerja perawat cenderung stabil sejak 0 tahun (tahun 2018) - tahun ke 5 (tahun 2023).

\section{Perilaku Submodel Motivasi}

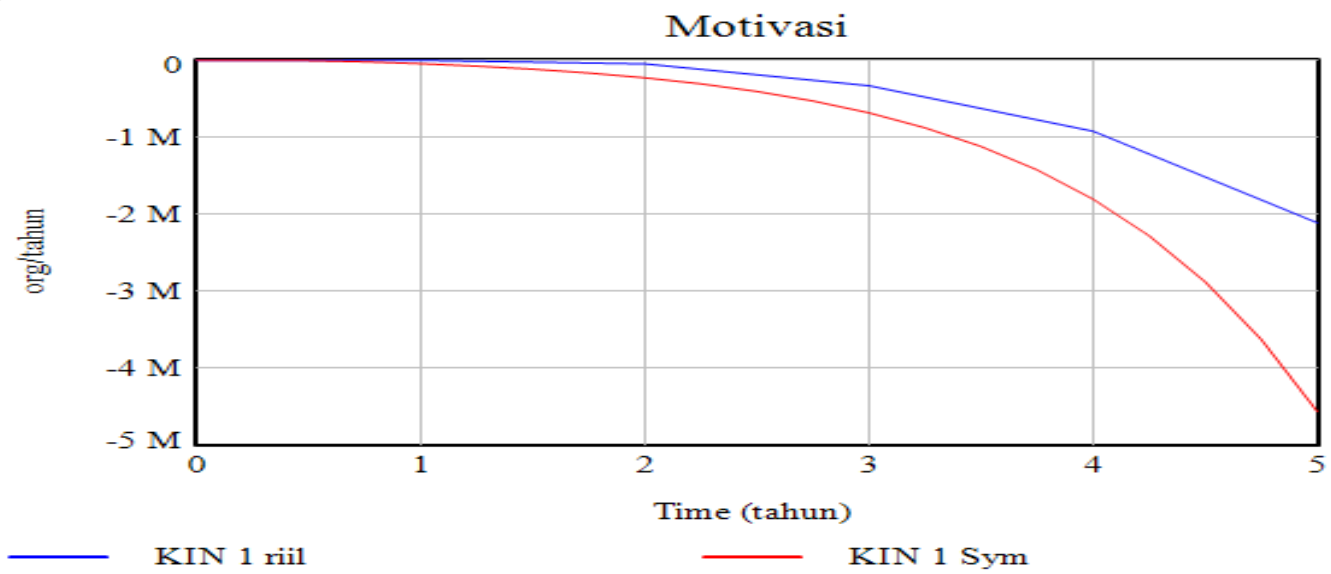

Gambar. 4

Grafik Perilaku Model Motivasi

Dapat dilihat perilaku motivasi perawat berdasarkan simulasi data historis (baserun, grafik line berwarna merah) dan simulasi setelah intervensi (reference mode, grafik line berwarna biru) dari awal simulasi tahun 2018 sampai 2023 sama-sama terjadi penurunan, namun penurunan jangka panjang yang terjadi pada hasil simulasi setelah intervensi cenderung lebih lamban. Hal ini karena belum ada kebijakan peningkatan motivasi yang dapat membuat motivasi perawat meningkat secara signifikan.

\section{Perilaku Submodel Program Pengembangan Pelatihan Perawat}

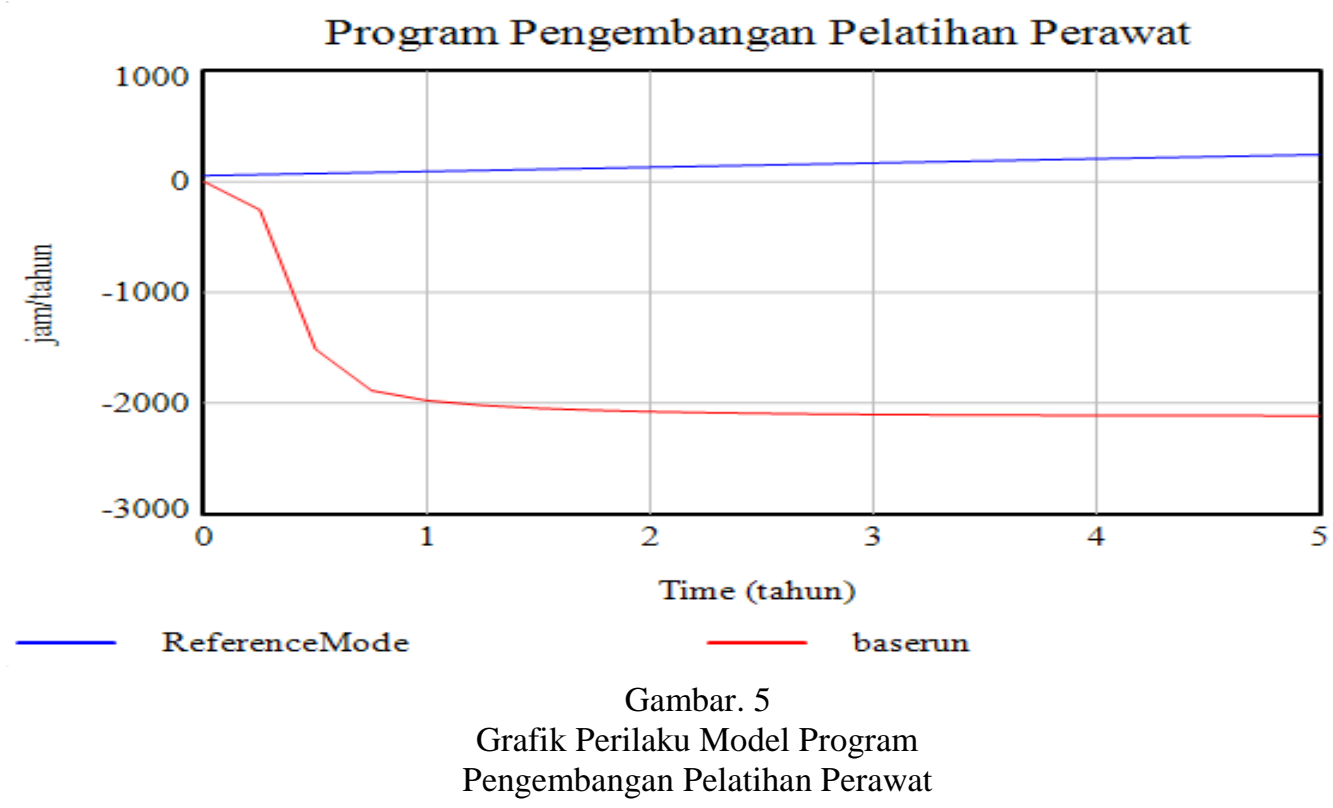


Dapat dilihat perilaku program pengembangan pelatihan perawat berdasarkan data historical yaitu 20 jam/tahun target waktu yang dijadikan indikator dalam kebijakan RSIJyang tertera dalam KPI yang ditampilkan pada file baserun (grafik line berwarna merah) dari awal mulai disimulasikan yaitu tahun 2018 sampai 2019 berada pada taraf penurunan signifikan dan berangsur turun hingga tahun ke 5 yaitu tahun 2023. Sedangkan bila program pengembangan pelatihan perawat disimulasikan untuk jangka panjang berdasarkan standar mutu profesi keperawatan (HPMI, 2017) yaitu 456 jam/tahun yang dalam gambar diatas ditampilkan dalam file reference mode (grafik line berwarna biru) tampak terjadi peningkatan yang terus menerus naik sejak awal tahun disimulasikan 2018 sampai tahun ke 5 yaitu tahun 2023.

Peneliti menarik kesimpulan bahwa hasil simulasi model perilaku program pengembangan pelatihan perawat menunjukkan jika dengan kebijakan 20 jam/tahun untuk setiap individu perawat dalam jangka panjang maka akan terjadi penurunan yang sangat signifikan, namun jika kebijakan tersebut ditingkatkan menjadi 456 jam/tahun maka akan terjadi peningkatan terus menerus dalam jangka panjang. Artinya meningkatkan kompetensi, kemampuan bekerja, kinerja dan motivasi perawat juga dapat dilakukan dengan upaya peningkatan program pelatihan baik internal maupun eksternal rumah sakit.

\section{Perilaku Submodel Kompetensi}

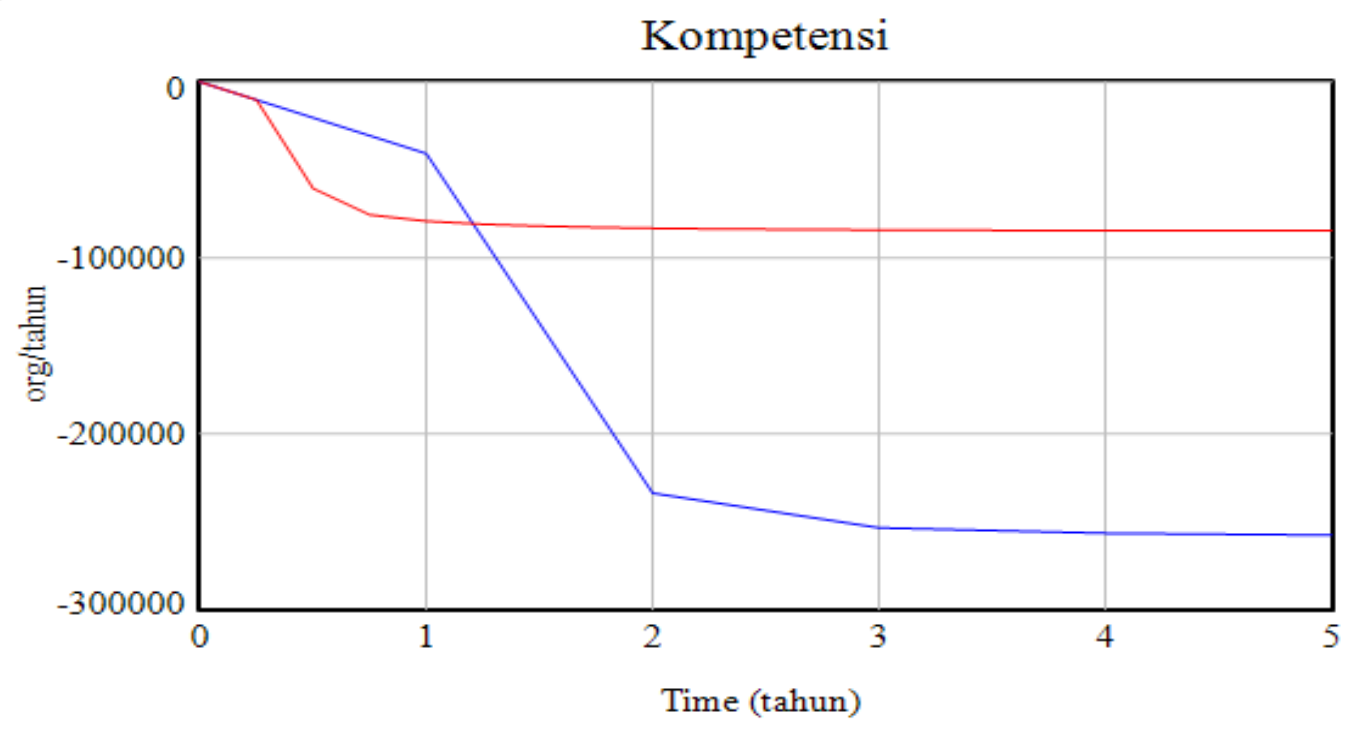

$\longrightarrow \quad$ KIN 1 riil

KIN 1 Sym

Gambar. 6

Grafik Perilaku Model Kompetensi

Dapat dilihat perilaku kompetensi perawat berdasarkan data historis (file KIN 1 riil; grafik line biru) dari awal tahun (2018) sampai 2020 berada pada taraf penurunan yang signifikan dan kemudian cenderung terus menurun sampai dengan tahun ke 5 (2023) dan setelah perilaku di simulasikan (KIN 1 Sym; gafik line merah) tetap terjadi penurunan kompetensi perawat namun tidak sesignifikan pada simulasi data historis, karena adanya delay kebijakan penambahan kebutuhan diklat, namun hal ini bisa pula diakibatkan pengurangan kompetensi karena usang. 


\section{Perilaku Submodel Kemampuan Bekerja}

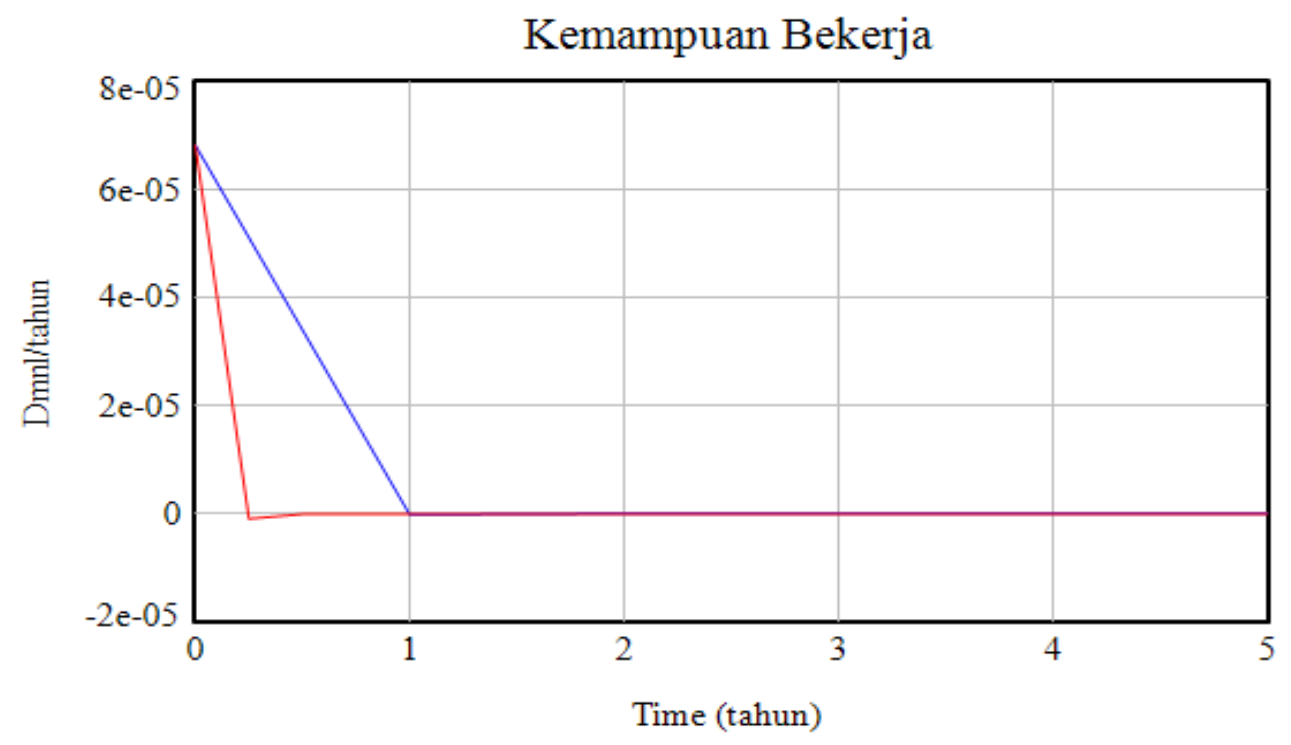

$\longrightarrow \quad$ KIN 1 riil

KIN 1 Sym

Gambar. 7

Grafik Perilaku Submodel Kemampuan Bekerja

Perilaku kemampuan bekerja perawat RSIJ Cempaka Putih perawat berdasarkan data historis (file KIN 1 riil; grafik line biru) dari awal tahun (2018) berada pada taraf penurunan yang signifikan dan kemudian cenderung tidak terjadi peningkatan atau tetap stabil diangka penurunan yang terjadi sejak awal tahun pertama sampai dengan tahun ke5 (2023) dan setelah perilaku disimulasikan (KIN1 Sym;grafik line merah) diawal tahun pertama simulasi pada dasarnya terjadi penurunan yang signifikan sampai tahun 2019 dan stabil sampai dengan tahun 2023 atau tidak ada terjadi peningkatan, hal ini dapat dilihat dari data-data yang telah ditampilkan pada bab sebelumnya bahwa hampir 60\% dari perawat RSIJ Cempaka Putih ini memiliki tingkat pendidikan Diploma ke atas. Selain itu pegawai yang bekerja hampir $65 \%$ diantaranya adalah perawat yang berpengalaman dalam keperawatan. Namun terjadi penurunan setelah satu tahun pertama dan tetap stabil sampai tahun ke 5 simulasi.

\section{PEMBAHASAN}

Berdasarkan hasil penelitian dari awal tahun 2018 sampai 2020 berada pada taraf penurunan yang signifikan dan kemudian cenderung terus menurun sampai dengan tahun ke 5 (2023) dan setelah perilaku disimulasikan (KIN 1 Sym; gafik line merah) tetap terjadi penurunan kompetensi perawat namun tidak sesignifikan pada simulasi data historis, karena adanya delay kebijakan penambahan kebutuhan diklat, namun hal ini bisa pula diakibatkan pengurangan kompetensi karena usang.

Menurut Wibowo (2007) kompetensi diperlukan untuk mengkomunikasikan nilai dan standar organisasi, menganalisis dan memperbaiki budaya organisasi, menyeleksi dan merekrut tenaga kerja, menilai dan mengembangkan tenaga kerja, mengembangkan pemimpin, mengelola proses perencanaan, membangun dasar untuk strategi pelatihan, dan membentuk proses kompensasi. 
Berdasarkan gambar di atas digambarkan program pengembangan pelatihan dalam upaya meningkatkan kinerja perawat sebagaimana dalam modifikasi teori Davis \& Newstrom (1985) dalam Sa'adah (2010) bahwa kinerja adalah perkalian antara motivasi dankemampuan bekerja. Dan kinerja ini akan mempengaruhi produktivitas potensial perawat yang membentuk kapasitas organisasi dan kemampuan organisasi melaksanakan beban pekerjaan yang menjadi tujuan organisasi.

Perilaku program pengembangan pelatihan perawat pada simulasi di atas menunjukkan bahwa sangat penting adanya strategi organisasi rumah sakit untuk meningkatkan jumlah jam pelaksanaan pelatihan internal dan eksternal dari 20 jam pertahun menjadi $456 \mathrm{jam} /$ pertahun sesuai dengan konsep yang dikemukakan oleh Priansa (2017) dalam Buku Putih 33 Area Keperawatan tentang program pengembangan kompetensi perawat berkelanjutan atau Continously Pactice Development (CPD) melalui pelatihan, supervisi dan bimbingan serta pembinaan di lapangan praktik keperawatan.

Sebagai efek dari kapasitas organisasi yang didukung oleh kebijakan RSIJ, maka tugas organisasi ini dapat dipenuhi. Karenanya hal ini akan mempengaruhi keputusan dalam program pengembangan pelatihan dan juga dalam menentukan keputusan untuk menambah atau mengurangi program pelatihan perawat untuk mendukung pencapaian tujuan. Dengan kata lain melalui pengukuran kinerja individu maka organisasi dapat mengetahui produktivitas kerjadan efekivitas serta efisiensi kerja perawat dan kemungkinan beban pekerjaan yang dapat terselesaikan dengan perawat yang ada dan dengan adanya kebijakan RS untuk meningkatkan kompetensi/keterampilan perawat melalui pelatihan internal dan eksternal maka kemampuan bekerja individu perawat akan sesuai dengan performance appraisal (penilaian kinerja) sehingga kinerja perawat akan meningkat yang dibuktikan dengan kemampuan dan produktivitas kerja yang maksimal. Program pengembangan pelatihan juga dapat berpengaruh secara tidak langsung terhadap motivasi perawat untuk bekerja maksimal (Nurhasanah \& Utama, 2014).

Perilaku kompetensi turun dengan sangat cepat di awal tahun simulasi seiring dengan produktivitas perawat yang menurun, selanjutnya hampir dapat dikatakan stabil dan tidak terjadi peningkatan hal ini disebabkan kebijakan peningkatan kompetensi sebenarnya dipengaruhi oleh kapasitas organisasi, kebijakan RSIJ untuk melaksanakan pelatihan sesuai dengan yang dibutuhkan, yang digambarkan dalam model ini kebijakannya hanya 0,5 artinya pelaksanaan diklat hanya dilaksanakan setengah dari kebutuhan peningkatan kompetensi perawat melalui pelatihan sebenarnya (Potter \& Perry, 2005).

Berdasarkan hasil simulasi diatas peneliti menarik kesimpulan bahwa kemampuan bekerja perawat RSIJ Cempaka Putih ini perilaku penurunannya cenderung stabil walaupun dengan kebijakan yang ada peningkatan kemampuan bekerja ini hanya terlihat di awal-awal tahun simulasi dan penurunan yang terjadi tetap stabil dan tidak terjadi peningkatan perilaku kemampuan bekerja jika dilihat perilakunya dalam jangka panjang. Perilaku ini dipengaruhi oleh tiga submodel penyusunnya yaitu perilaku kompetensi, kemampuan bekerja potensial dan faktor kesesuaian, dimana submodel faktor kesesuaian merupakan factor eksogen yang artinya tidak dipengaruhi oleh sub model lainnya.

Dengan menggunakan metoda system dynamics dalam pengelolaan kinerja, maka pemilihan alternatif kebijakan yang akan diimplementasikan ke dunia nyata dapat dilakukan dengan lebih tepat dan lebih efisien melalui analisis perilaku hasil simulasi 
model. Simulasi model ini juga akan memudahkan pemahaman para pengambil kebijakan terhadap permasalahan yang telah terjadi serta prediksi perilaku yang akan terjadi atas implementasi berbagai solusi kebijakan ditawarkan.

Dengan menggunakan metodologi system dynamics dapat dilakukan counter intuitive atas anggapan yang selama ini ada bahwa dengan meningkatkan kesejahteraan pegawai maka akan meningkatkan motivasi dan pada akhirnya meningkatkan kinerja. Anggapan tersebut tidak sepenuhnya benar karena kinerja perawat tidak hanya dipengaruhi oleh besarnya insentif yang diterima perawat melainkan faktor reward dalam bentuk pengembangan perawat dengan memberikan pelatihan internal dan eksternal yang sesuai dengan kompetensinya yang perlu diperhatikan untuk meningkatkan motivasi perawat yang selanjutnya akan meningkatkan kinerjanya.

Pengelolaan program pengembangan pelatihan perawat perlu dilakukan secara terpadu (integrated) dari semua aspek dan tidak konstan tetapi harus invasif baik dari segi materi maupun target waktu terutama dalam kaitannya dengan peningkatan kompetensi, motivasi dan kemampuan bekerja perawat. Struktur model pengelolaan program pengembangan pelatihan perawat dengan menitikberatkan pada pengelolaan kinerja individu memperlihatkan adanya keterkaitan antara variabel-variabel dalam manajemen SDM yang saling mempengaruhi satu sama lain. Penurunan kinerja perawat dalam jangka panjang sangat dipengaruhi oleh motivasi perawat yang juga menurun dalam jangka panjang, begitupula dengan kemampuan bekerja pegawai yang menurun signifikan di awal tahun simulasi dimulai dan penurunan tersebut cenderung menetap/stabil dalam jangka panjang.

Dengan metodologi sistem dinamik dapat dilakukan implementasi kebijakan yang lebih terencana terutama dari sisi waktu implementasi. Di dalam penelitian ini dapat dilihat bahwa implementasi kebijakan peningkatan program pengembangan pelatihan, kompetensi, motivasi, dan insentf dapat dilaksanakan secara bertahap. Sesuai dengan skenario yang direkomendasikan yaitu ada 3 skenario (program pengembangan pelatihan, peningkatan kinerja, motivasi).

\section{SIMPULAN}

Kinerja perawat RSIJ Cempaka Putih sebenarnya menunjukan perilaku yang menurun, berbeda dengan kinerja yang dilaporkan berdasarkan Key Performnce Indicator (KPI) dan Performance Appraisal bahwa kinerja perawat dominan sesuai standar sampai istimewa.

\section{SARAN}

\section{Untuk Rumah Sakit Islam Jakarta Cempaka Putih}

Implementasi kebijakan peningkatan program pengembangan pelatihan pegawai dengan strategi manajemen pengetahuan (knowledge management) secara perlahan dimulai pada tahun 2019.

Implementasi kebijakan peningkatan kompetensi perawat dengan strategi pelatihan berbasis kompetensi (competency based training) secara bertahap dimulai pada tahun 2019.

Implentasi kebijakan peningkatan motivasi pegawai melalui promosi dan mutasi pegawai dengan basis informasi kinerja pegawai, dapat dilakukan secara bertahap. Dimulai dengan penilaian kinerja perawat selain KPI dan performance appraisal yang dapat menyuguhkan informasi kinerja masing-masing individu perawat, kemudian dilanjutkan dengan kebijakan promosi dan mutasi pegawai sesuai dengan hasil penilaian 
kinerja.

Implementasi kebijakan peningkatan pemberian insentif, disesuaikan dengan kemampuan keuangan daerah. Sedikit demi sedikit dimulai tahun 2018 ini.

\section{Untuk Penelitian Selanjutnya}

Pada penelitian ini masih banyak digunakan data-data asumsi serta faktor-faktor yang bersifat eksogenus yang belum diakomodir di dalam model. Untuk penelitian selanjutnya data-data tersebut dapat digali lebih tajam dari berbagai sumber, sedangkan faktor-faktor eksogenus bisa masuk sebagai variabel endogenus, seperti faktor kesesuaian kemampuan bekerja, pengaruh kebijakan terhadap kapasitas organisasi. Variabel-variabel dalam penelitian ini masih digambarkan secara sederhana seperti proses promosi atau mutasi yang bisa digali lebih dalam lagi.

Selain itu dalam penelitian ini masih kurang digali pengaruh kinerja ini terhadap faktor-faktor diluar individu perawat, misalnya pengaruhnya terhadap kinerja organisasi atau produktivitas organisasi yang pada perkembangannya bisa mempengaruhi keberhasilan organisasi.

\section{DAFTAR PUSTAKA}

Departemen Kesehatan RI. (2004). Keputusan Menteri Kesehatan Republik Indonesia Nomor 1197/Menkes/SK/X/2004

HPMI. (2017). The Role of Nurse Managers to Achieve Proffesional Practice Through the Strengthening of Regulation and Social Welfare Economics. Term of Reference. Himpunan Perawat Manajer Indonesia

Nurhasanah, N ., \& Utama, Y. T. (2014). Simulasi System Dynamic (Dinamika Sistem) untuk Memprediksi Keberhasilan Strategi Pengembangan Laboratorium Prodi Teknik Industri di UAI .Jurnal Al-Azhar Indonesia Seri Sains dan Teknologi, 2(3). 129-142. https://media.neliti.com/media/publications/29092077ddbc56.pdf

Potter, P., \& Perry, P. (2005). Buku Ajar Fundamental Keperawatan, Konsep, Proses, dan Praktik, Edisi 4. Jakarta: EGC

Priansa, J. D. (2017). Manajemen Kinerja Kepegawaian dalam Pengelolaan SDM Perusahaan. Bandung: Pustaka Setia Bandung

Rohmatullah, R. (2017). Pengembangan Model System Dynamic (Dinamika Sistem) Kinerja Pabrik Gula. $2^{\text {nd }}$ Workshop on System Modelling for Policy Development: Rehersing Strategic Initiatives Jakarta. Bogor: Departemen Teknologi Industri Pertanian IPB

Sa'adah, S. F. (2010). Analisis Kebijakan Peningkatan Kinerja Sumber Daya Manusia (Sdm) Aparatur Pemerintah Kota Bandung dengan Pendekatan System Dynamics (Studi pada Badan Kepegawaian Daerah Kota Bandung). Tesis. Institut Teknologi Bandung. Bandung

SDM RSIJ Cempaka Putih. (2015). Format Monitoring dan Evaluasi Kinerja Pegawai. RSIJ Cempaka Putih. Jakarta

Undang-Undang RI Nomor 44 Tahun 2009 tentang Rumah Sakit. Jakarta

Wibowo, W. (2007). Manajemen Kinerja. Edisi 3. Jakarta: Rajawali Pers 